\title{
Articles
}

\section{Are Adult Educators and Learners 'Digital Immigrants'? Examining the Evidence and Impacts for Continuing Education}

\author{
Erika Smith, University of Alberta
}

\begin{abstract}
Over the past decade, Prensky's distinctions between "digital immigrants" and "digital natives" have been oft-referenced. Much has been written about digital native students as a part of the Net generation or as Millennials. However, little work fully considers the impact of digital immigrant discourse within the fields of adult learning and continuing education. It is promising that rather than being digitally challenged immigrants for whom new learning technologies are completely foreign, adults of different ages can bring valuable knowledge and skills to e-learning environments that enable them to achieve academic success. These are important findings, since e-learning is increasingly recognized as an important part of learning across the life-course. With the growing body of research evidence countering common digital native and immigrant distinctions and critiquing an underlying technological determinism informing such arguments, how might practitioners respond to these discourses in their own educational contexts? With a focus on digital immigrants, the purpose of this article is to provide critical
\end{abstract}

\begin{abstract}
RÉsumé
Au cours de la dernière décennie, on a souvent fait référence aux distinctions que fait Prensky entre les «immigrants numériques » et les « natifs numériques ». Beaucoup de choses ont été écrites au sujet des étudiants de la génération $Y$ en tant que génération Internet ou du millénaire. Toutefois, peu de travaux considèrent dans leur ensemble les répercussions du discours des immigrants numériques dans les domaines de l'apprentissage des adultes et de la formation continue. Il est prometteur de savoir que, plutôt que d'être des immigrants numériques pour qui les nouvelles technologies pédagogiques représentent un défi, les adultes de tous âges peuvent migrer leurs précieuses connaissances et compétences vers des environnements d'apprentissage en ligne qui leur permettent d'atteindre la réussite scolaire. Il s'agit là de découvertes importantes, puisque l'apprentissage en ligne est de plus en plus reconnu comme une partie importante de l'apprentissage en cours de vie. Avec la croissance du nombre de données factuelles issues de la recherche qui contrecarrent les distinctions communes entre les natifs et les immigrants
\end{abstract}

Canadian Journal of University Continuing Education / Vol. 39, No. 1, spring 2013

Revue Canadienne de L'Éducation Permanente Universitaire / Vol. 38, No 1 printemps 2012

http://ejournals.library.ualberta.calindex.php/cjuce-rсepu 
Are Adult Educators and Learners 'Digital Immigrants'?

consideration of current research evidence on digital native/immigrant distinctions that impact educators and learners within the field of continuing education. numériques et qui critiquent le déterminisme technologique sous-jacent amenant de tels arguments, comment les praticiens peuventils répondre à ces discours dans leurs propres contextes pédagogiques? En mettant l'accent sur les immigrants numériques, l'objectif de cet article est de rendre une analyse critique des preuves scientifiques actuelles quant aux distinctions entre les natifs et les immigrants numériques, qui ont des répercussions sur les pédagogues et les apprenants dans le domaine de la formation continue.

\section{INTRODUCTION}

But Digital Immigrants typically have very little appreciation for these new skills that the Natives have acquired and perfected ... Digital Immigrants think that learning can't (or shouldn't) be fun.

Marc Prensky

Distinctions between "digital immigrants" and "digital natives" (Prensky, 2001a; Prensky, 2001b) have been frequently referenced over the past decade. Much has been written about digital native students as a part of the Net generation (Tapscott, 1998; Tapscott, 2008) or as Millennials (Howe \& Strauss, 2000), which generally includes learners "born in the 1980s and later" (Oblinger \& Oblinger, 2005, p. 1.2). However, little work fully considers the impact of digital immigrant discourse as it appears within the field of adult learning and continuing education. Indeed, such discussion seems increasingly necessary given the growing body of recent evidence calling into question such popular, binary notions characterizing youth as ubiquitously techsavvy digital natives and older generations as techno-challenged digital immigrants. Researchers who are critical of these characterizations demonstrate that there is just as much variation within these generations as between them (Bennett, Maton, \& Kervin, 2008; Bullen, Morgan, \& Qayyum, 2011; Jones, Ramanau, Cross, \& Healing, 2010). Since e-learning is increasingly recognized as an important part of learning across the life-course (Canadian Council on Learning, 2009), understanding current research evidence on educational technologies across and beyond generational boundaries is an important issue. With a lens on digital immigrants, the purpose of this article is to foster further dialogue and reflection on immigrant/native distinctions as they impact adult educators and learners within the field of continuing education by providing a discussion of these critical contemporary issues.

Canadian Journal of University Continuing Education / Vol. 39, No. 1, spring 2013

Revue Canadienne de L'Éducation Permanente Universitaire / Vol. 39, No 1 printemps 2013

http://ejournals.library.ualberta.calindex.php/cjuce-rcepu 


\section{Digital Native and Immigrant Distinctions Demystified}

In what is often dubbed the twenty-first century learning environment, age-based claims made regarding digital natives and digital immigrants have become an important issue for educators, administrators, and students alike. In seminal yet controversial writings published around the turn of the twenty-first century, thinkers such as Tapscott (1998) describe the Net generation, and Howe and Strauss (2000) describe Millennial students as digital natives possessing technological knowledge and skills that older digital immigrants lack. In particular, Prensky's influential two-part article "Digital Natives, Digital Immigrants" (2001a, 2001b) fuelled a number of subsequent publications in which a variety of researchers and practitioners take up this message of an urgent need to recognize and adapt to the characteristics of a new digital generation of students. The discourse reflected in publications purporting digital native enthusiasm has been influential within the context of educational-technology research, policy, and practice (for practice-based examples, see Brown, 2002; Frand, 2000; Oblinger, 2003; Oblinger \& Oblinger, 2005; for research-based examples, see James, 2011; Kruger, 2010; Kumar, 2009; Patterson, 2009). As I outline in an analysis of recent literature on the digital native debate in higher education (Smith, 2012), authors such as Howe and Strauss (2000), Prenksy (2001a), and Tapscott (1998) largely began the digital native discussion by arguing that this unique generation of young learners who were born after 1980 has new educational and technological needs and abilities because they have always known a world with digital technologies and the Internet. Such characterizations strongly differentiate between digital natives and digital immigrants, and these characterizations continue to be engaged and debated in contemporary educational research and practice, particularly as they concern emerging learning technologies.

\section{Defining Digital Natives and Digital Immigrants}

Digital natives are portrayed as unique because they have grown up immersed in and surrounded by digital technologies as a part of their everyday lives, and are said

1. to constitute a largely homogenous generation and to speak a different language vis-à-vis digital technologies, as opposed to their parents, the digital immigrants;

2. to learn differently from preceding generations of students;

3. to demand a new way of teaching and learning involving technology. (Thomas, 2011, p. 4)

These popular claims within the seminal literature on digital natives (for example, that digital natives possess a sophisticated set of ICT [Information and Communication Technologies] knowledge and skills or that they have different learning styles or preferences) are largely unsupported by research evidence (Bennett, Maton, \& Kirvan, 2008, p. 777). However, using these claims, enthusiasts present digital natives as a part of a utopian vision of technology tied to an exoticized picture of liberated young people (Buckingham, 2011). Despite slight distinctions, the terms digital native, the Net generation, and Millennials are used interchangeably (Jones et al., 2010, p. 723).

Digital immigrants are characterized as individuals born before 1980 who knew an analogueonly world and still rely on analogue forms of interaction. For digital immigrants, the communication changes happening via the introduction of digital technologies are supposedly learned and relearned, instead of easily becoming second nature (Palfrey and Gasser, 2008, p. 4). Problems are often identified not with the digital natives but rather with older generations of non-natives who display their "digital

Canadian Journal of University Continuing Education / Vol. 39, No. 1, spring 2013

Revue Canadienne de L'Éducation Permanente Universitaire / Vol. 39, No 1 printemps 2013

http://ejournals.library.ualberta.calindex.php/cjuce-rcepu 
immigrant accent" (Prensky, 2001a, p. 3) when using new technologies. In this way, digital immigrants are portrayed as being tied to older media, unable to catch up (Buckingham, 2011), therefore embodying the antithesis of digital natives.

Given the binary nature of these definitions (one is either considered a digital native, or not, on the basis of age), digital native and immigrant discussions frequently centre on dichotomies distinguishing between those who possess certain qualities versus those who do not. Indeed, the nature of digital native discourse itself further reflects polarities between digital native proponents who are "techno-evangelists" and digital native skeptics who are technophobic dissenters (Thomas, 2011). As such, the digital native and immigrant debate to date often reflects polarities and binary positions, via both the nature of the arguments being presented and in the metaphors and analogies employed to illustrate these points. Furthermore, in interrogating the nature and form of the claims comprising key arguments within digital native debates, it becomes clear that "technological determinism" is a foundational undercurrent of digital native discourse (Bennett \& Maton, 2010; Jones, 2011; Oliver, 2011; Selwyn, 2012). To move beyond such polarized positions, several thinkers propose finding the nuances within a more balanced discussion that avoids the tropes underlying earlier digital native discussions (Bennett \& Maton, 2010; Buckingham, 2011; Bullen et al., 2011; Kennedy, Judd, Dalgarno, \& Waycott, 2010; Thomas, 2011). Still, as we will see in the following discussion, debates about digital natives and digital immigrants persist in many educational settings today, often reinforcing and reflecting common claims and the associated underlying technological determinism.

\section{Common Digital Natives Claims}

Digital native proponents argue that young students both act and think differently than older generations, who are so-called digital immigrants. According to Prensky (2001a), there is a clear distinction between these viewpoints that must be recognized: "Do we see the future through the eyes of a cyber immigrant or a cyber native?" (p. 3). A comparative analysis of recent literature shows that the following eight recurring and controversial assertions concerning digital natives continue to characterize Net generation students as (1) possessing new ways of knowing and being, (2) driving a digital revolution transforming society, (3) being innately or inherently techsavvy, (4) multi-tasking, team-oriented, and collaborative, (5) being native speakers of the language of technologies, (6) embracing gaming, interaction, and simulation, (7) demanding immediate gratification, and (8) reflecting and responding to the knowledge economy (Smith, 2012). Though these characteristics are still embedded in some contemporary e-learning research and practice, recent analyses challenge such broad characterizations (Bennett et al., 2008; Bullen et al., 2011; Guo, Dobson, \& Petrina, 2008; Hargittai, 2010; Jones \& Healing, 2010; Kennedy et al., 2010; Margaryan, Littlejohn, \& Vojt, 2011). Yet, while much has been written about the impact of the digital native discourse, few have further considered the impact of digital native and immigrant distinctions within adult learning and continuing education. With this understanding of digital native claims in mind, it is valuable to turn to an examination of common digital immigrant claims.

\section{Common Digital Immigrant Claims}

The term digital immigrant has been used to generally describe older educators and parents born prior to 1980. Prensky describes the importance of this distinction between natives and immigrants as speakers of the "language" of technology in the following way:

The "digital immigrant accent" can be seen in such things as turning to the Internet for information second rather than first, or in reading the manual for a program rather than assuming that the program itself will teach us to use it. Today's older folk were "socialized"

Canadian Journal of University Continuing Education / Vol. 39, No. 1, spring 2013

Revue Canadienne de L'Éducation Permanente Universitaire / Vol. 39, No 1 printemps 2013

http://ejournals.library.ualberta.calindex.php/cjuce-rсepu 
Are Adult Educators and Learners 'Digital Immigrants'?

differently from their kids ... [T] he single biggest problem facing education today is that our Digital Immigrant instructors, who speak an outdated language (that of the pre-digital age), are struggling to teach a population that speaks an entirely new language. (2001a, p. 3)

In relation to technology, aspects of language, literacy, and communication are often used as important distinguishers between natives who purportedly possess fluency and immigrants who are learning something foreign. Tapscott states that many digital immigrants still "don't get" the urgent need to recognize how "in reality, today's digital natives have made technology a natural and necessary part of their daily communication efforts" (Devaney, 2010, p. 1). Brown also makes a distinction between educators and students by citing differences in language: "Today's generation of students communicates in a language that many academics don't yet understand" (2002, pp. 80-81). In a related way, several influential Net-gen sources (e.g., Oblinger \& Oblinger, 2005) link age and generational categories to digital literacy, and information and communication technology (ICT) competency. However, recent research studies present a varied picture of young people's digital literacy knowledge and skills that challenges such descriptions, showing that not all young people uniformly possess these competencies (Bullen et al., 2011; Erstad, 2011; Kennedy \& Judd, 2011). Furthermore, contrary to common digital immigrant assertions, Helsper and Eynon (2010) argue that "adults, specifically teachers, can 'speak the same language' as their students if they want to" (p. 15). These examples illustrate how distinctions contrasting digital immigrants and natives remain to be a contested but important contemporary issue for those encountering generational issues of technology in the classroom.

Some so-called digital immigrant educators, themselves, employing native/immigrant distinctions in order to underscore an urgent need for educators across disciplines and domains to recognize their digital immigrant status and rapidly adapt to technological changes. For example, Copeland (2011) urges immigrant educators in the field of choral direction to quickly adapt to change, arguing that technological ignorance "usually results in irrelevancy, a condition that renders teachers ineffective in their communication with others and impairs the ability to effect positive change in the lives of students" (p. 28). In the context of medical education, Sandars (2006) paints himself and his counterparts as older "digital immigrants who, like all newcomers, tend to feel clumsy in a new environment" (p. 516), in contrast to young native students who have an intuitive sense of technology. Similarly, Norton-Meiers (2011) presents an urgent call for fellow educators working within the realm of adult and adolescent literacy to "face the digital divide and the uncomfortable place we find ourselves in as digital immigrants" (p. 431). The examples demonstrate how those outside the Net generation may paint themselves as digital immigrants, thereby reinforcing problematic digital native and immigrant distinctions presented by Tapscott (1998) and Prensky (2001a).

\section{Evidence on Educators as Digital Immigrants}

Recent research has begun to delve further into the evidence regarding such distinctions, particularly as it relates to the ICT uses and perceptions of older adults who are educators. Noting that few studies examine how adults might develop ICT literacy differently from younger people, Guo et al., (2008) examined how age demographics affect student-teacher perceptions of ICT skills and literacy, as well as how age effects ICT literacy competency. Their analysis showed no statistically significant difference in ICT scores between immigrants and natives, suggesting that differences between these groups have been exaggerated and do not hold up in practice (Guo et al., 2008, pp. 251-252). Likewise, Waycott, Bennett, Kennedy, Dalgarno, and Gray's (2010) findings question prevalent descriptions of native students and immigrant teachers in higher education,

Canadian Journal of University Continuing Education / Vol. 39, No. 1, spring 2013

Revue Canadienne de L'Éducation Permanente Universitaire / Vol. 39, No 1 printemps 2013

http://ejournals.library.ualberta.calindex.php/cjuce-rcepu 
Are Adult Educators and Learners 'Digital Immigrants'?

and emphasize a "need to develop a more sophisticated understanding about the role technologies play in the lives of both students and staff" (p. 1202). Similar findings presented by Salajan, Schönwetter, and Cleghorn (2010) show only slight inter-generational differences between students and faculty members when looking at perceptions of the importance and usefulness of digital technologies for teaching and learning, and the authors conclude that these differences are "minimal, with no universal applicability" (p. 1393). The evidence presented in these studies problematizes simplistic divisions between digital natives and immigrants, instead suggesting that older adult educators may not in fact display digital immigrant characteristics in practice. Other recent studies present similar findings challenging common notions about digital natives and immigrants because these ideas reflect and inform the practice of teachers and faculty members outside of the Net generation. For instance, in light of the impact of this discussion on teachers in particular, Toledo (2007) compares digital tourists, immigrants, and natives and concludes that these issues often highlight the importance of technology access and preferences: "[t]he propensity to immerse oneself in technology, to create a technology-rich educational environment, and to take advantage of the strengths of technology in the classroom are all functions of exposure and interest, not age" (p. 91). White and Le Cornu (2011) also discuss new directions for a typology of online learners that take into account such issues via a continuum of visitors and residents. Related to users' access to technologies as an important issue, Lorimer and Hilliard's (2007) study of student and staff evaluations of podcasting and e-voting in blended learning demonstrated "no discernable differences in the behavior" of students because both direct entry and mature learners were able to access these technologies easily (p. 407). In addition, they found that teaching teams also believed that blended learning increased student engagement. While there is increasing evidence that questions assumptions of educators outside the Net generation as digital immigrants, further research and discussion is needed on adult learners who may erroneously be assumed to fit within digital native and immigrant categories because of their age.

\section{Adult Learners and Online Learning}

As noted earlier, e-learning is increasingly viewed as an important part of learning across the life-course (Canadian Council on Learning, 2009). Given the perceived importance of e-learning for adult and continuing education, it is valuable to examine recent evidence questioning whether adult learners exhibit digital immigrant qualities in online settings.

\section{Adults in Online Learning Environments: Are They Digital Immigrants?}

While little research appears to have investigated adult learners as digital immigrants in continuing education settings, emerging evidence concerning adults in online learning environments is beginning to shed some light on these issues. Berenson, Boyles, and Weaver (2008) found that emotional intelligence (EI) and personality are important factors in predicting learners' academic success in online courses; interestingly, they also point to a positive correlation between age and EI-that is, "the older the participants, the greater their emotional intelligence" (pp. 11-12). In contrast to the dominant digital immigrant discourse, older learners may bring EI traits that can contribute to academic success in online courses. These findings are supported by Ransdell's (2010) subsequent small-scale study of students in the health sciences, which found that as a "surprisingly strong variable, chronological age was as predictive as was

Canadian Journal of University Continuing Education / Vol. 39, No. 1, spring 2013

Revue Canadienne de L'Éducation Permanente Universitaire / Vol. 39, No 1 printemps 2013

http://ejournals.library.ualberta.calindex.php/cjuce-rcepu 
critical thinking disposition" for learning outcomes in an online course (p. 72). Positing that motivation to think critically can improve online learning, her study concluded that Millennialaged students "were those with the lowest critical-thinking skill and dispositions, and the lowest grades in the class ... contrary to popular wisdom, older students may make better online learners than younger" (p. 70). For those working in the field of adult and continuing education where online learning is increasingly viewed as an important asset, these findings are useful in countering simplistic digital native and immigrant assumptions by emphasizing the importance of teaching students about EI, critical thinking, and other skills that contribute to online learning success. These results also illustrate how mature learners may in fact be able to achieve academic success and learning outcomes in various online contexts.

It is important to consider in this discussion of online learning that many formal online courses use a learning management system (LMS) that may not incorporate other emerging web technologies that so-called digital natives are purported to be familiar with (such as social networking applications). What remains unclear from the above-mentioned studies is how natives or immigrant learners would fare comparatively in their online learning when using emerging web technologies beyond those within a standard LMS set up. Kennedy et al.'s (2007) preliminary study of digital native students' use of emerging web technologies does discuss use of social media, finding that "use of collaborative and self-publishing 'Web 2.0' technologies that have often been associated with this generation is quite low" (p. 17). In a subsequent study, when investigating differences between student and staff use of emerging technologies, Kennedy et al. (2008) found few differences between groups and that overall use of these technologies was low, although they note that the frequency of technology usage may reasonably be expected to have increased since their survey was carried out in 2006 (pp. 489-490). They found that "there were no role, gender or age effects for technology-based activities associated with Web 2.0 technologies" (p. 484). Bullen et al.'s (2011) study shows similar results. Again, while these studies provide valuable insights, it is still unclear how natives and immigrant learners would fare comparatively when using these emerging web technologies for their online learning. Subsequent studies could investigate whether similar findings would emerge when examining online learning using emerging web technologies across age boundaries.

\section{Learning with Technology Across the Lifespan}

Recent studies on cognition and learning processes are also beginning to shed valuable light on the digital immigrant discussion by looking at how people learn with technology across their lifespan. Petrina, Feng, and Kim (2007) emphasize the importance of examining generational issues within native/immigrant constructs that are not supported by empirical data of learning across the lifespan: "The digital native-immigrant framework overlooks processes of learning together (e.g., intergenerational learning) and mistakenly identifies cross-generational differences as a form of 'digital divide'"' (pp. 376-377). They provide a comprehensive description of how adults and older adults learn, though this discussion is somewhat complicated by the broadness of these categories (they use the word "adults" to refer to post-secondary students and other mature learners in the workplace and the term "older adults" to refer to seniors over the age of 65). The authors bring to the fore several important points about cognition and learning processes as they relate to adult learning with technology. One point the authors highlight is that seniors may be at a disadvantage when learning new technologies, and these older adults, in particular, can "feel anxious and threatened by technological changes," but they can also "learn to moderate their skills and make changes to their everyday routines and tasks" (pp. 383-384). Further inquiry into learning technologies across the lifespan, especially the differences and interconnections that may exist between young adult, mature adult, and senior adult learning processes, would help to further probe whether perceptions of older generations as anxious about learning technologies may be accurate in some circumstances.

Canadian Journal of University Continuing Education / Vol. 39, No. 1, spring 2013

Revue Canadienne de L'Éducation Permanente Universitaire / Vol. 39, No 1 printemps 2013

http://ejournals.library.ualberta.ca/index.php/cjuce-rcepu 
In furthering our understanding of not only the intersections between learners but also changes in learners at different ages, it is useful to articulate a more detailed definition of age and generational categories. With a focus on digital immigrants, Ransdell, Kent, GaillardKenney, and Long (2010) studied digital native/immigrant qualities of four birth-year cohorts in the context of specific generational categories: Millennials (born after 1982), Generation X (born 1971-82), younger Boomers (born 1961-72), and older Boomers (born 1951-62). They concluded that digital non-native status as well as active participation and social reliance in the classroom result in better knowledge application:

Millennial students were more likely to be digital natives, showed poorer knowledge application skill and were more self-reliant than older students. Older boomers represented the most socially-reliant learners, and were better at knowledge application... [they] were also more active in the websites associated with the online courses and were more likely to be digital immigrants rather than natives. (p. 931)

The authors show not only the value of investigating the differences between age groups of learners but also the importance of considering factors such as social reliance and locus of control when exploring digital native/immigrant issues. Recent studies such as these confirm the need for future research investigating these complex factors of educational psychology and sociology, especially as we grapple with such issues in different adult and continuing education contexts.

\section{Relationship to Practice}

As an instructional designer and educational-technology practitioner, I first became interested in the complex array of student and educator perspectives of emerging learning technologies when I began working in the field of educational technology over seven years ago. During my time working with e-learning in continuing education, I have witnessed the benefits of emerging learning technologies for advancing access to education, bridging barriers between traditionally separate informal, non-formal, and formal contexts in ways that are unprecedented. Indeed, it is an exciting time to be an instructional designer and e-learning practitioner.

I have seen learners and educators who are excited and engaged by technologies - when used thoughtfully and intentionally, such emerging learning technologies can be employed to extend and enhance teaching and learning in a variety of face-to-face, blended, and online educational settings. I have also seen learners and educators who have different learning characteristics and viewpoints engage with learning technologies in new and interesting ways. These experiences lead me to believe that the simply binary divisions between digital immigrant and natives are more complex when they unfold in practice. As the evidence outlined above illustrates, what is important to recognize is that popular, yet over-simplified, distinctions between digital natives and immigrants do not appear to hold up when investigated in practice.

As an instructional designer who, like many of my colleagues, uses research-informed approaches to improve practice when examining problematic digital native and digital immigrant distinctions present within contemporary research and practice discourses, I am reminded of the ever-pressing importance of recognizing and responding to claims that reinforce technological determinism in our own educational settings. In recognizing the role that we play in (re)focusing educational discussions on the pedagogical considerations and human agency that can inform technological affordances, I am also reminded of Campbell, Schwier, and Kenny's (2009) emerging model of change agency as a part of the critical, relational practice of instructional design. Of course, generations do not all use technologies in the same way or for the same reasons, but, as Bullen et al.'s (2011) research illustrates, there are important contextual differences in why and how we use technologies for learning that transcend age. The crux of these issues highlights a need

Canadian Journal of University Continuing Education / Vol. 39, No. 1, spring 2013

Revue Canadienne de L'Éducation Permanente Universitaire / Vol. 39, No 1 printemps 2013

http://ejournals.library.ualberta.ca/index.php/cjuce-rcepu 
for investigating anew such complex relationships among and between age groups, and within various educational contexts. Investigating these issues anew within adult and continuing education situations appears to be an area that needs particular attention.

While I have seen many benefits of educational technologies, I am also cognizant of the potential danger of focusing on technological drivers rather than human capacities within our educational settings, which may merely propel prevalent trends. As Kanuka (2008) states,

Often swept up by unbridled - but uninformed - enthusiasm by technological advocates, many decisions by educators are based on following the latest trend. Unfortunately, these strategies often lead to incongruence and inconsistency in action between and among instructors, administrators, and students, and the ensuing disagreements that revolve around the means rather than the ends of education. (p. 111)

When we fail to examine technologies with a critical eye, we risk losing sight of the pedagogical goals and underpinnings upon which such technical initiatives should be founded. It is my hope that the discussion of digital immigrant issues provided underscores this point: if educators and learners are to fully realize the transformational potential of learning technologies, we must identify and break down the stated and unstated assumptions embedded within prominent educational and technological theories and practice. To this end, rather than simply embrace digital native and digital immigrant distinctions, we must continue to critically investigate and discuss the assumptions within the dominant discourse of immigrants and natives occurring in our educational settings.

\section{CONCLUSION}

As evidence challenging simplistic distinctions between digital natives and immigrants begins to take shape, there must also be renewed recognition that our understanding of learners cannot be so absolute. Instead, we must continue to deconstruct the assumptions at the heart of this digital native and immigrant discourse, to move towards and make room for alternative viewpoints. As adult audiences increasingly look to e-learning strategies for their educational programs, understanding and interrogating such assumptions remains an important contemporary issue for the field of continuing education. The analysis provided above highlights several key themes that may inform this continued discussion and prompts us to consider the following questions:

- Upon further study, particularly of emerging technologies (e.g., social media, mobile learning, etc.), will there continue to be few (if any) notable differences between learners within different age groups and generations?

- Will future research investigate whether "older students may make better online learners than younger" (Ransdell, 2010, p. 70), and do such inquiries need to take into greater account the importance of context?

- Is there any value at all in considering similarities and differences between types of adult learners across the lifespan (young adults, mature adults, seniors) in their use and understanding of learning technologies, or should we simply move beyond the focus on generational categories?

- In terms of cognition and learning technology over the lifespan, will further study increase our understanding of the intersections between and changes of learners at different ages?

Such questions could help initiate an involved and critical dialogue between researchers, policy makers, administrators, e-learning practitioners, and learners within the realm of adult and continuing education about authentic e-learning theories and approaches for their learning

Canadian Journal of University Continuing Education / Vol. 39, No. 1, spring 2013

Revue Canadienne de L'Éducation Permanente Universitaire / Vol. 39, No 1 printemps 2013

http://ejournals.library.ualberta.calindex.php/cjuce-rcepu 
Are Adult Educators and Learners 'Digital Immigrants'?

audiences. Contrary to Prensky's (2001a, 2001b) assertion that digital immigrants do not appreciate the new skills required for educational and technological success, it is promising that the evidence outlined above paints a picture of adult learners who can bring an array of valuable knowledge and skills to their learning environments. It is now our task to bring to light both why and how learners and educators of all ages may leverage learning technologies in authentic and potentially transformative ways.

\section{REFERENCES}

Berenson, R., Boyles, G., \& Weaver, A. (2008). Emotional intelligence as a predictor for success in online learning. The International Review of Research in Open and Distance Learning, 9, 1-18. Retrieved from http://www.irrodl.org/index.php/irrodl

Bennett, S., Maton, K., \& Kervin, L. (2008). The 'digital natives' debate: A critical review of the evidence. British Journal of Educational Technology, 39(5), 775-786. doi:10.1111/j.1467-8535.2007.00793.x

Bennett, S., \& Maton, K. (2010). Beyond the 'digital natives' debate: Towards a more nuanced understanding of students' technology experiences. Journal of Computer Assisted Learning, 26(5), 321-331. doi:10.1111/j.1365-2729.2010.00360.x

Buckingham, D. (2011). Foreword. In M. Thomas (Ed.), Deconstructing digital natives: Young people, technology and the new literacies (pp. iv-xi). New York: Routledge.

Bullen, M., Morgan, T., \& Qayyum, A. (2011). Digital learners in higher education: Generation is not the issue. Canadian Journal of Learning Technology, 37(1), 1-24. Retrieved from http:// www.cjlt.ca/index.php/cjlt

Brown, J. S. (2002). Learning in the Digital Age. In M. Devlin \& J. Meyerson (Eds.), The Internet \& the University: Forum 2001 (pp. 65-91). Forum for the Future of Higher Education and EDUCAUSE. Retrieved from net.educause.edu/ir/library/pdf/FFPIU015.pdf

Campbell, K., Schwier, R. A., \& Kenny, R. F. (2009). The critical, relational practice of instructional design in higher education: An emerging model of change agency. Educational Technology Research and Development, 57(5), 645-663. doi: 10.1007/s11423-007-9061-6

Canadian Council on Learning. (2009, May). State of e-Learning in Canada. Retrieved from http:// www.ccl-cca.ca/CCL/Reports/StateELearning.html

Copeland, P. L. (2011). Digital natives and immigrant choral directors: Catching up and reaching out. Choral Journal, 51(8), 27-35.

Devaney, L. (2010, January 26). Tapscott: Digital natives need tech-rich education. eSchool News. Retrieved from http://www.eschoolnews.com/2010/01/26/ digital-natives-need-tech-rich-education/

Erstad, O. (2011). Citizens navigating in literate worlds: The case of digital literacy. In M. Thomas (Ed.), Deconstructing digital natives: Young people, technology and the new literacies (pp. 99-117). New York: Routledge.

Frand, J. L. (2000). The information-age mindset: Changes in students and implications for higher education. EDUCAUSE Review, September/October 2000, 15-24. Retrieved from http://net.educause.edu/ir/library/pdf/ERM0051.pdf

Canadian Journal of University Continuing Education / Vol. 39, No. 1, spring 2013

Revue Canadienne de L'Éducation Permanente Universitaire / Vol. 39, No 1 printemps 2013

http://ejournals.library.ualberta.calindex.php/cjuce-rcepu 
Are Adult Educators and Learners 'Digital Immigrants'?

Guo, R. X., Dobson, T., \& Petrina, S. (2008). Digital natives, digital immigrants: An analysis of age and ICT competency in teacher education. Journal of Educational Computing Research, 38(3), 235-254. doi: 10.2190/EC.38.3.a

Hargittai, E. (2010). Digital na(t)ives? Variation in Internet skills and uses among members of the "Net Generation." Sociological Inquiry, 80(1), 92-113. doi:10.1111/j.1475-682X.2009.00317.x

Helsper, E., \& Eynon, R. (2010). Digital natives: Where is the evidence? British Educational Research Journal, 36(3), 503-520. doi:10.1080/01411920902989227

Howe, N., \& Strauss, W. (2000). Millennials rising: The next great generation. New York, NY: Vintage.

James, P. J. (2011). Mobile-learning: Thai HE student perceptions and potential technological impacts. International Education Studies, 4(2), 182-194. doi:10.5539/ies.v4n2p182

Jones, C. (2011). Students, the Net generation, and digital natives: Accounting for educational change. In M. Thomas (Ed.), Deconstructing digital natives: Young people, technology and the new literacies (pp. 30-45). New York: Routledge.

Jones, C., \& Healing, G. (2010). Net generation students: Agency and choice and the new technologies. Journal of Computer Assisted Learning, 26(5), 332-343. doi:10.1111/j.1365-2729.2010.00370.x

Jones, C., Ramanau, R., Cross, S., \& Healing, G. (2010). Net generation or digital natives: Is there a distinct new generation entering university? Computers $\mathcal{E}$ Education, 54, 722-732. doi:10.1016/j.compedu.2009.09.022

Kanuka, H. (2008). Understanding e-learning technologies-in-practice through philosophies-inpractice. In T. Anderson (Ed.), The theory and practice of online learning (2nd ed.), pp. 91-118. Retrieved from http://www.aupress.ca/index.php/books/120146

Kennedy, G., Dalgarno, B., Bennett, S., Judd, T., Gray, K., \& Chang, R. (2008). Immigrants and natives: Investigating differences between staff and students' use of technology. In Hello! Where are you in the landscape of educational technology? Proceedings ASCILITE Melbourne 2008 (pp. 484-492). Retrieved from http://www.ascilite.org.au/conferences/melbourne08/procs/ kennedy.pdf

Kennedy, G., Dalgarno, B., Gray, K., Judd, T., Waycott, J., Bennett, S., ... Churchward, A. (2007). The Net generation are not big users of Web 2.0 technologies: Preliminary findings. In ICT: Providing choices for learners and learning. Proceedings ASCILITE Singapore 2007, (pp. 517-525). Retrieved from http://www.ascilite.org.au/conferences/singapore07/procs/kennedy.pdf

Kennedy, G. K., \& Judd, T. S. (2011). Beyond Google and the "satisficing" searching of digital natives. In M. Thomas (Ed.), Deconstructing digital natives: Young people, technology and the new literacies (pp. 119-136). New York: Routledge.

Kennedy, G., Judd, T., Dalgarno, B., \& Waycott, J. (2010). Beyond natives and immigrants: Exploring types of net generation students. Journal of Computer Assisted Learning, 26(5), 332-343. doi:10.1111/j.1365-2729.2010.00371.x

Kruger, M. (2010). Students' changing perceptions on the impact of the online learning environment: What about good teaching practice? Proceedings of the European Conference on e-Learning, 188-196.

Kumar, S. (2009). Undergraduate perceptions of the usefulness of web 2.0 in higher education: Survey development. Proceedings of the European Conference on e-Learning, 308-314.

Canadian Journal of University Continuing Education / Vol. 39, No. 1, spring 2013

Revue Canadienne de L'Éducation Permanente Universitaire / Vol. 39, No 1 printemps 2013

http://ejournals.library.ualberta.calindex.php/cjuce-rcepu 
Are Adult Educators and Learners 'Digital Immigrants'?

Lorimer, J., \& Hilliard, A. (2007). Net gen or not gen? Student and staff evaluations of the use of podcasts/audio files and an electronic voting system (EVS) in a blended learning module. In D. Remenyi (Ed.), Proceedings of the 6th European conference on e-Learning (pp. 407-414). Reading, UK: Academic Publishing Limited.

Margaryan, A., Littlejohn, A., \& Vojt. G. (2011). Are digital natives a myth or reality? University students' use of digital technologies. Computers E Education, 56(2), 429440. doi: 10.1016/j. compedu.2010.09.004

Norton-Meiers, L. (2005). Joining the video-game literacy club: A reluctant mother tries to join the "flow." Journal of Adolescent \& Adult Literacy, 48(5), 428-432. Retrieved from http://www. jstor.org/stable/40013807

Oblinger, D. (2003). Boomers, gen-Xers \& Millennials: Understanding the new students. EDUCAUSE Review, July/August 2003, 37-47. Retrieved from http://www. educause.edu/EDUCAUSE+Review/EDUCAUSEReviewMagazineVolume38/ BoomersGenXersandMillennialsUn/157842

Oblinger, D., \& Oblinger, J. (2005). Introduction. In D. Oblinger \& J. Oblinger (Eds.), Educating the Net Generation (1.1-1.5). Boulder, CO: EDUCAUSE. Retreived from: http:// www. educause.edu/educatingthenetgen

Oliver, M. M. (2011). Technological determinism in educational technology research: Some alternative ways of thinking about the relationship between learning and technology. Journal of Computer Assisted Learning, 27(5), 373-384. doi:10.1111/j.1365-2729.2011.00406.x

Palfrey J. \& Gasser U. (2008). Born digital: Understanding the first generation of digital natives. New York: Basic Books.

Patterson, S. (2009). Creating a virtual library classroom tool for digital age youth. New Knowledge Environments, 1(1), 1-8. Retrieved from http://journals.uvic.ca/index.php/INKE/

Petrina, S., Feng, F., \& Kim, J. (2007). Researching cognition and technology: How we learn across the lifespan. International Journal of Technology and Design Education, 18(4), 375-396. doi:10.1007/s10798-007-9033-5

Prensky, M. (2001a). Digital natives, digital immigrants part 1. On the Horizon, 9(5), 1-6. Retrieved from http://www.emeraldinsight.com/journals.htm?issn=1074-8121

Prensky, M. (2001b). Digital natives, digital immigrants part 2: Do they really think differently? On the Horizon, 9(6), 1-6. Retrieved from http://www.emeraldinsight.com/journals. htm?issn=1074-8121

Ransdell, S. (2010). Motivation, reasoning, and online activity among health science students. Computers in Human Behavior, 26(1), 70-73. doi:10.1016/j.chb.2009.09.002

Ransdell, S., Kent, B., Gaillard-Kenney, S., \& Long, J. (2010). Digital immigrants fare better than digital natives due to social reliance. British Journal of Educational Technology. 42(6), 931-938. doi:10.1111/j.1467-8535.2010.01137.x

Salajan, F. D., Schönwetter, D. J., \& Cleghorn, B.M. (2010). Student and faculty inter-generational digital divide: Fact or fiction? Computers \& Education, 55(3), 1393-1403. doi:10.1016/j. compedu.2010.06.017

Sandars. J. (2006). The e-learning site. Education for Primary Care, 17(5), 516-517.

Canadian Journal of University Continuing Education / Vol. 39, No. 1, spring 2013

Revue Canadienne de L'Éducation Permanente Universitaire / Vol. 39, No 1 printemps 2013

http://ejournals.library.ualberta.ca/index.php/cjuce-rcepu 
Are Adult Educators and Learners 'Digital Immigrants'?

Selwyn, N. (2012). Making sense of young people, education and digital technology: The role of sociological theory. Oxford Review of Education, 38(1), 81-96. doi: 10.1080/03054985.2011.577949

Smith, E. E. (2012). The digital native debate in higher education: A comparative analysis of recent literature. Canadian Journal of Learning and Technology, 38(3). Retrieved from http:// www.cjlt.ca/index.php/cjlt

Tapscott, D. (1998). Growing up digital: The rise of the Net generation. New York: McGraw-Hill.

Tapscott, D. (2008). Grown up digital: How the Net generation is changing your world. New York: McGraw-Hill.

Thomas, M. (2011). Technology, education, and the discourse of the digital native: Between evangelists and dissenters. In M. Thomas (Ed.), Deconstructing digital natives: Young people, technology and the new literacies (pp. 1-11). New York: Routledge.

Toledo, C. (2007). Digital culture: Immigrants and tourists responding to the natives' drumbeat. International Journal of Teaching and Learning in Higher Education, 19(1), 84-92. Retrieved from http://www.isetl.org/ijtlhe/

Waycott, J., Bennett, S., Kennedy, G., Dalgarno, B., \& Gray, K. (2010). Digital divides? Student and staff perceptions of information and communication technologies. Computers $\mathcal{E}$ Education, 54(4), 1202-1211. doi:10.1016/j.compedu.2009.11.006

White, D. S., \& Le Cornu, A. (2011). Visitors and residents: A new typology for online engagement. First Monday, 16(9). Retrieved from http:/firstmonday.org/htbin/cgiwrap/bin/ojs/ index.php/fm/index

\section{BIOGRAPHY}

Erika Smith is an Instructional Designer in the University of Alberta's Faculty of Extension, specializing in designing engaging online learning experiences. She is currently completing her $\mathrm{PhD}$ in Educational Policy Studies at the University of Alberta, where she studies digital native/ digital immigrant discourse within higher education practice.

Erika Smith est conceptrice pédagogique au département d'éducation permanente (Faculty of Extension) de l'Université de l'Alberta et se spécialise dans la conception d'expériences d'apprentissage électronique stimulantes. Elle termine présentement son doctorat en études de politiques éducatives à l'Université de l'Alberta, où elle étudie le discours des natifs/immigrants numériques dans la pratique de l'enseignement supérieur.

Canadian Journal of University Continuing Education / Vol. 39, No. 1, spring 2013

Revue Canadienne de L'Éducation Permanente Universitaire / Vol. 39, No 1 printemps 2013

http://ejournals.library.ualberta.calindex.php/cjuce-rcepu 